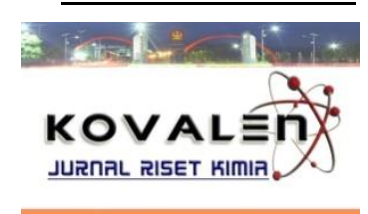

\title{
PEMANFAATAN SANTAN INSTAN KADALUARSA UNTUK PRODUKSI MINYAK SECARA FERMENTASI
}

\author{
[Utilization of Expired Istant Coconut Milk for Oil Production by Fermentation] \\ Megmerio Soro"), Syaiful Bahri ${ }^{\left.1^{*}\right)}$, Erwin Abdul Rahim ${ }^{1)}$ \\ 1) Jurusan Kimia Fakultas MIPA, Universitas Tadulako \\ J. Soekarno Hatta Km.9, Kampus Bumi Tadulako Tondo Palu, Telp. 0451- 422611
}

Diterima 10 Mei 2016, Disetujui 8 Agustus 2016

\begin{abstract}
This research use the expired instant coconut milk for 2 months. The goal is to find out whether the coconut milk can be used to produce oil. The method does is with variation of the total number of laru $0,5 \mathrm{~mL}$ oil; $0,75 \mathrm{~mL} ; 1 \mathrm{~mL} ; 1,25 \mathrm{~mL}$; and $1,50 \mathrm{~mL}$ by volume per volume $(\mathrm{v} / \mathrm{v})$. the fermentation time and 18 hours, 24 hours, 30 hours, and 36 minutes. Results of the study that the amount of oil the oil laru yield the highest oil is $1,50 \mathrm{~mL}$ with $28 \%$ yield and fermentation time of 30 hours, while the lowest was at the time of fermentation 18 hours i.e. $15 \%$.
\end{abstract}

Keywords: instant coconut milk, expired, coconut oil, yeast, oil, quality and yield.

\begin{abstract}
ABSTRAK
Penelitian ini menggunakan santan instan yang telah kadaluarsa selama 2 bulan. Tujuannya adalah untuk mengetahui apakah santan tersebut dapat digunakan untuk menghasikan minyak. Metode yang dilakukan adalah dengan variasi jumlah laru minyak $0,5 \mathrm{~mL} ; 0,75 \mathrm{~mL} ; 1 \mathrm{~mL} ; 1,25 \mathrm{~mL}$; dan $1,50 \mathrm{~mL}$ berdasarkan volume per volume (v/v). dan waktu fermentasi 18 jam; 24 jam; 30 jam; dan 36 jam. hasil penelitian yang diperoleh adalah jumlah laru minyak yang menghasilkan rendemen minyak tertinggi adalah $1,50 \mathrm{~mL}$ dengan rendemen $28 \%$ dan waktu fermentasi 30 jam sedangkan terendah adalah pada waktu fermentasi 18 jam yaitu $15 \%$
\end{abstract}

Kata Kunci: Santan instan, kadaluarsa, santan kelapa, laru minyak, minyak, Mutu dan rendemen. 


\section{LATAR BELAKANG}

Kelapa merupakan salah satu tanaman yang dapat digunakan dalam pembuatan minyak. Minyak yang dihasilkan banyak digunakan masyarakat sebagai minyak goreng. Pembuatan minyak kelapa secara tradisional dilakukan dengan pemanasan pada suhu tinggi, mengakibatkan banyak terjadi kerusakan. Sebagai contoh, pemanasan yang tinggi dapat menyebabkan minyak teroksidasi serta menghasilkan warna minyak kurang baik. (Adi dan Amprasto 1995). Minyak yang baik banyak dihasilkan dari kelapa yang sudah tua.

Buah kelapa yang sudah tua atau matang umumnya dipanen pada umur 1112 bulan (Rindengan dkk, 1995). Oleh karena itu buah kelapa yang sesuai untuk diolah menjadi minyak kelapa murni harus berumur 12 bulan (Rindengan dkk 1995). Komposisi kimia daging buah kelapa ditentukan oleh umur buah kelapa pada berbagai tingkat kematangan. Kelapa segar mengandung $30-50 \%$ minyak, kadar minyak sangat dipengaruhi oleh tingkat ketuaan buah, semakin tua buah semakin tinggi kadar minyaknya.

Santan kelapa merupakan produk hasil olahan, untuk memperoleh kekentalan santan yang diperoleh sebaiknya ditambahkan emulsifier sehingga emulsinya lebih stabil (Hasbullah, 2001). Menurut Andriani (2002), santan murni mengandung protein sebesar 4,2 gr per $100 \mathrm{gr}$, serta kandungan mineral lainnya. Menurut Djatmiko (1983), varietas kelapa akan mempengaruhi komposisi kimia santan kelapa hasil ekstraksi daging buah kelapa. Hasil santan dan total padatan naik dengan semakin matangnya buah.

Santan kelapa merupakan cairan hasil ekstraksi dari kelapa parut dengan menggunakan air. Bila santan didiamkan, secara pelan-pelan akan terjadi pemisahan bagian yang banyak mengandung minyak dan dengan bagian yang sedikit mengandung minyak. Bagian yang banyak mengandung minyak disebut krim, dan bagian yang sedikit mengandung minyak disebut skim. Krim lebih ringan dibanding skim, karena krim berada pada bagian atas, dan skim pada bagian bawah.

Santan adalah emulsi minyak dalam air yang berwarna putih, yang diperoleh dengan cara memeras daging kelapa segar yang telah diparut atau dihancurkan dengan atau tanpa penambahan air, (Tansakul dan Chaisawang, 2006). Pemanfaatan santan pada umumnya adalah untuk produksi minyak, bahan campuran masak dan pembuatan kue.

\begin{tabular}{rrr}
\multicolumn{2}{c}{ Perkembangan teknologi yang } \\
semakin pesat
\end{tabular}
kecenderungan masyarakat mencari cara penggunaan sesuatu bahan yang bersifat praktis, mudah penyediaan dan penggunaannya, serta mempunyai daya simpan yang lama. Oleh karena itu, telah dilakukan pembuatan santan dalam bentuk siap pakai, antara lain dibuat menjadi santan instan (Anggrahini, 1999).

Saat ini telah banyak beredar dipasaran santan siap pakai dari berbagai 
merek, salah satu adalah santan instan. Santan instan mempunyai waktu simpan atau masa kadaluarsa yang mempunyai waktu simpan selama 1 tahun, setelah waktu tersebut santan tidak lagi dapat digunakan dalam arti harus dibuang. Di daerah perkotaan misalnya Jakarta, pembuangan skim santan kadaluarsa menjadi permasalahan yang disebabkan karena jumlahnya cukup banyak. Pada sisi lain santan instan kadaluarsa masih mungkin dijadikan sebagai bahan baku untuk produksi minyak terutama minyak yang bukan untuk konsumsi (Biodisel).

Salah satu cara yang dapat dilakukan untuk mendapatkan minyak kelapa adalah dengan memanfaatkan kegiatan mikroorganisme yang dikenal dengan cara fermentasi. Pembuatan minyak kelapa dengan fermentasi merupakan alternatif untuk mengatasi masalah pada pembuatan dengan cara tradisional. Pembuatan minyak kelapa dengan fermentasi membutuhkan waktu cukup lama tetapi tidak membutuhkan proses pemanasan untuk mendapatkan minyaknya (Arsa dkk, 2004). Fermentasi dilakukan dengan menggunakan mikroorganisme sebagai inokulum seperti bakteri dan khamir. Pembuatan minyak kelapa secara fermentasi ini dapat dilakukan dalam skala besar maupun rumah tangga. Cara fermentasi memiliki beberapa keuntungan pokok yaitu efisien dalam tenaga, waktu relatif singkat dan biaya tidak terlalu tinggi serta tidak butuh peralatan yang rumit. Minyak kelapa yang dihasilkan lebih banyak dan warnanya lebih jernih (Sukmadi \& Nugroho, 2002).

Dalam menentukan kualitas minyak, Kadar air merupakan parameter yang mempengaruhi tingkat ketahanan minyak terhadap kerusakan. Menurut Kataren (1986) terdapatnya sejumlah air dalam minyak atau lemak dapat mengakibatkan terjadinya reaksi hidrolisis. yang menghasilkan asam lemak bebas (FFA). Asam lemak, dihasilkan melalui reaksi hidrolisis yang dapat disebabkan oleh sejumlah air, enzim ataupun aktivitas mikroorganisme . semakin tinggi kadar air dalam minyak kemungkinan besar kadar asam lemak juga tinggi. Selain Kadar airnya. Bilangan peroksida merupakan parameter penting yang dapat dijadikan acuan untuk menentukan derajat kerusakan minyak. Peroksida terbentuk karena asam lemak tidak jenuh dapat mengikat oksigen pada ikatan rangkapnya (Kataren, 1986). Proses itu dikenal sebagai proses oksidasi.

Proses pemanfaatan santan instan kadaluarsa untuk pembuatan minyak dipengaruhi oleh banyaknya biang atau laru yang ditambahkan dan lamanya waktu fermentasi yang dilakukan. Berdasarkan pernyataan diatas peneliti ingin melakukan penelitian untuk memanfaatkan santan instan kadaluarsa untuk produksi minyak.

\section{METODE PENELITIAN}

\section{Bahan dan Alat}

Bahan dasar yang digunakan dalam penelitian ini adalah Skim Santan 
Kadaluarsa selama 2 bulan yang diperoleh dari pasar Masomba Palu, dan Mikroorganisme khamir (laruh minyak). Aquades, $\mathrm{KOH} 0,1 \mathrm{~N}$, Asam Oksalat 0,1N Etanol $96 \%$, indikator PP, Asam asetat 60 $\%$, Kloroform $40 \%$, Kalium lodida jenuh, Natrium Tiosulfat $0,01 \mathrm{~N}$.

Peralatan yang digunakan dalam penelitian ini mencakup Mikser, plastik roll, pipet mikro, statif dan klem, penangas air, neraca analitik, oven dan alat gelas yang umum digunakan di laboratorium kimia.

\section{Prosedur Penelitian}

\section{Produksi Minyak dari Santan instan Kadaluarsa Secara Fermentasi}

Menyiapkan santan instan yang sudah kadaluarsa atau sudah lewat waktu penyimpanannya, dibagi menjadi 4 perlakuan masing-masimg sebanyak $40 \mathrm{ml}$. setelah itu diencerkan santan kelapa baru masing-masing sebanyak 5,10,15,dan 20 $\mathrm{mL}$. Kemudian ditambahkan air masingmasing sebanyak $200 \mathrm{ml}$. Selanjutnya santan instan encer masing-masing diberi laru minyak sebanyak $1 \mathrm{ml} / \mathrm{L}$, Campuran diinkubasi selama 24 jam. Setelah itu ditentukan rendemen minyak yang dihasilkan. Hasil penambahan santan baik yang menghasilkan rendemen minyak terbanyak dilakukan penambahan laruh dengan variasi laruh $0,5 \mathrm{ml} / \mathrm{L} ; 0,75 \mathrm{ml} / \mathrm{L} ; 1$ $\mathrm{ml} / \mathrm{L} ; 1,25 \mathrm{ml} / \mathrm{L} ;$ dan $1,5 \mathrm{ml} / \mathrm{L}(\mathrm{v} / \mathrm{v})$, dan diinkubasi selama 24 jam.

\section{Penentuan Waktu Fermentasi Santan Instan Kadaluarsa}

Hasil perlakuan terbaik menggunakan laruh minyak, diinkubasi dengan variasi waktu perlakuan yaitu 18 jam, 24 jam, 30 jam, dan 36 jam. Setelah itu dipisahkan minyak yang diperoleh dengan komponen lainnya. Selanjutnya ditentukan rendemen minyak yang dihasilkan.

\section{Uji Mutu Minyak Santan Instan Kadaluarsa Menurut Ketaren (1986) dalam (Suastuti, 2009)}

\section{a. Bilangan Asam}

Penentuan bilangan asam dilakukan dengan cara titrasi menggunakan larutan basa $\mathrm{KOH}$. Adapun cara penetuannya, yaitu ditimbang sebanyak 5 gram minyak kelapa, kemudian ditambahkan dengan etanol $97 \%$. Campuran tersebut selanjutnya dipanaskan sampai mendidih selama 10 menit di atas penangas air sambil diaduk-aduk.Setelah dingin selanjutnya dititrasi dengan larutan $\mathrm{KOH}$ $0,1 \mathrm{~N}$ dengan menggunakan fenolftalin sebagai indikator sampai terbentuk warna merah muda. Dilakukan pengulangan penentuan sebanyak tiga kali. Larutan $\mathrm{KOH} 0,1 \mathrm{~N}$ yang digunakan untuk titrasi distandarisasi dengan larutan asam oksalat $0,1 \mathrm{~N}$.

Perhitungan :

$$
\text { Bil.Asam }=\frac{\mathrm{mL} \mathrm{KOH} \mathrm{x} \mathrm{M} \mathrm{KOH} \mathrm{x} \mathrm{BM} \mathrm{Asam} \mathrm{Lemak}}{\text { Bobot Minyak }}
$$

\section{b. Bilangan peroksida}

Adapun cara Penentuan Bilangan Peroksida penentuannya, yaitu ditimbang minyak seberat 5 gram, kemudian memasukkan kedalam Erlenmeyer $250 \mathrm{ml}$. Menambahkan $30 \mathrm{ml}$ campuran pelarut yang terdiri dari $60 \%$ asam asetat dan $40 \%$ kloroform. Menambahkan 0,5 ml lautan kalium iodide jenuh sambil dikocok 
setelah minyak larut. Menambahkan aquadest sebanyak $30 \mathrm{ml}$. Menitrasi dengan larutan natrium thiosulfat $0,01 \mathrm{~N}$. Mencatat volume larutan natrium thiosulfat yang digunakan.

Miliekuivalen per $1000 \mathrm{gram}=\frac{\mathrm{A} \times \mathrm{N} \times 1000}{\mathrm{G}}$ Ket:

$A=$ jumlah $\mathrm{ml}$ larutan natrium thiosulfat $\mathrm{N}=$ normalitas larutan natrium thiosulfat $\mathrm{G}=$ berat contoh minyak (gram)

\section{HASIL DAN PEMBAHASAN}

\section{Rendemen Minyak Fermentasi Santan Instan pada Berbagai Perlakuan.}

Santan merupakan emulsi minyak dalam air yang diperoleh dengan cara memeras daging buah kelapa segar yang telah dihaluskan. Beberapa peneliti telah melakukan penelitian untuk meningkatkan waktu penyimpanan santan. Santan instan kadaluarsa dapat diolah menghasilkan minyak untuk digunakan sebagai konsumsi atau biodiesel. Suhadijono dan Syamsiah (1988), melakukan uji coba pembuatan minyak kelapa melalui proses fermentasi.

Pembuatan minyak kelapa secara fermentasi ini didasarkan pada asumsi, bahwa lapisan protein yang melindungi globula dalam santan akan mudah rusak. Hal ini diakibatkan oleh aktivitasa mikrobia yang menghasilkan asam saat proses fermentasi. Pengaruh volume santan instan kadaluarsa terhadap rendemen minyak yang dihasilkan dapat diketahui dengan menerapkan berbagai volume penambahan santan kelapa. Hasil yang diperoleh menunjukan rendemen minyak tertinggi $(33,5 \%)$ terdapat pada penggunaan penambahan santan kelapa baru $10 \mathrm{ml}$, dan rendemen terendah (19\%) ditemukan pada penggunaan penambahan santan kelapa $5 \mathrm{ml}$ dengan masing-masing diberi laru minyak sebanyak $1 \mathrm{ml}$. Hubungan volume santan kelapa dengan rendemen minyak yang dihasilkan diperlihatkan pada Gambar 1 sebagai berikut.

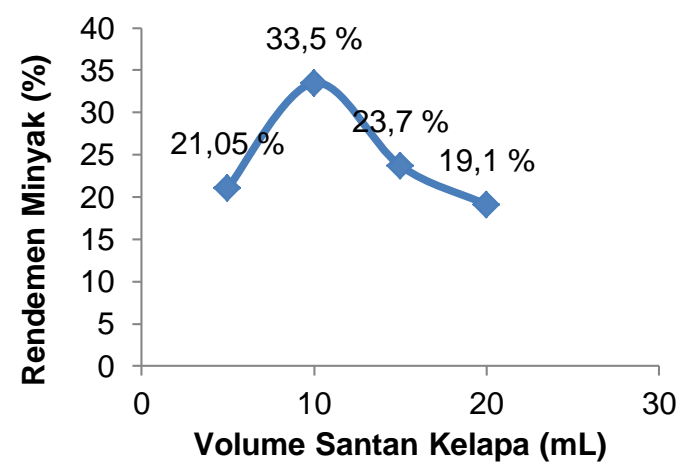

Gambar 1 Kurva hubungan penambahan volume santan kelapa terhadap rendemen minyak

Gambar 1 memperlihatkan bahwa dengan penambahan volume santan kelapa baru $10 \mathrm{~mL}$ sebagai volume total menjadi $50 \mathrm{~mL}$ rendemen minyak yang dihasilkan tertinggi adalah (33,5\%) dengan penambahan santan kelapa baru setelah itu dengan penambahan selanjutnya kadar minyak menurun, dengan semakin banyak bertambahnya volume santan maka konsentrasi laru semakin kecil dalam santan sehingga aktivitas semakin menurun sehingga jumlah minyak yang dihasilkan menurun. Volume santan kelapa, dan penamabahan laru minyak (ragi minyak) dapat mempengaruhi minyak yang dihasilkan. Ragi minyak menghidrolisis protein yang terdapat pada santan yang berperan sebagai elmusifier 
pada santan. Rusaknya protein maka emulsi minyak dan air pada santan akan rusak dan minyak akan terpisah dari air dengan sendirinya. Bertambahnya volume santan kelapa, maka proses hidrolisis protein pada santan akan berlangsung lebih baik sehingga jumlah minyak yang dihasilkan akan lebih banyak. Tetapi hal yang terjadi semakin banyak volume santan kelapa yang ditambahkan maka minyak yang dihasilkan dapat menurun. Seperti terdapat pada gambar 1 kemungkinan hal tersebut dapat berkaitan dengan santan instan kadaluarsa dan laru minyak. Semakin banyak santan instan kadaluarsa sehingga laru minyak menjadi encer maka konsentrasi menurun sehingga minyak yang dihasilkan sedikit.

Hasil analisis sidik ragam menujukan bahwa perlakuan variasi volume santan kelapa berbeda tidak nyata terhadap rendemen minyak yang dihasilkan. Penambahan santan kelapa pada santan instan kadaluarsa masing-masing dilakukan dengan variasi penambahan 5 $\mathrm{ml}, 10 \mathrm{ml}, 15 \mathrm{ml}$, dan $20 \mathrm{ml}$. Hasil menujukan bahwa rendemen minyak yang terbanyak atau tertinggi berada pada penambahan santan kelapa $10 \mathrm{ml}$.

Pembuatan minyak kelapa secara fermentasi santan instan tidak kadaluarsa sebagai pembanding, dari santan instan kadaluarsa diatas. Pengaruh volume santan instan tidak kadaluarsa terhadap rendemen minyak yang dihasilkan dapat diketahui dengan menerapkan berbagai volume penambahan santan kelapa. Hasil yang diperoleh menunjukan rendemen minyak tertinggi $(31,6 \%)$ terdapat pada penggunaan penambahan santan kelapa baru $20 \mathrm{ml}$, dan rendemen terendah $(24,4 \%)$ ditemukan pada penggunaan penambahan santan kelapa $5 \mathrm{ml}$ dengan masing-masing diberi laru minyak sebanyak $1 \mathrm{ml}$. Hubungan volume santan kelapa dengan rendemen minyak yang dihasilkan diperlihatkan pada Gambar 2 sebagai berikut.

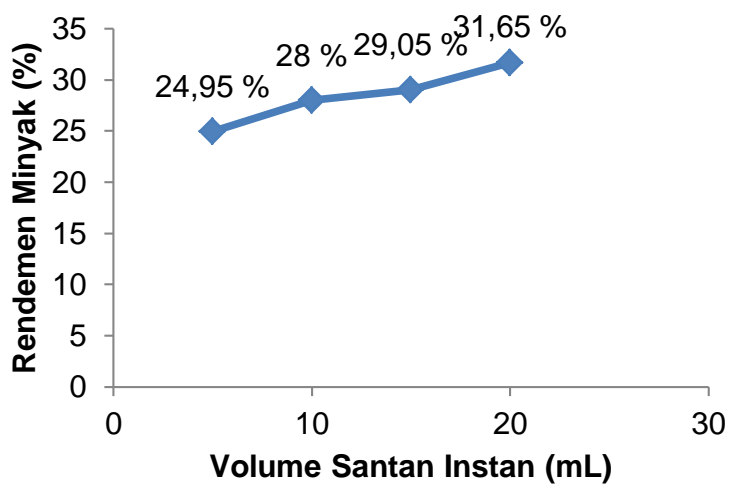

Gambar 2 Kurva hubungan penambahan volume santan kelapa terhadap rendemen minyak

Gambar 2 memperlihatkan bahwa dengan penambahan volume santan kelapa baru $20 \mathrm{~mL}$ sebagai volume total menjadi $60 \mathrm{~mL}$ rendemen minyak yang dihasilkan tertinggi adalah $(31,6 \%)$ dengan penambahan santan kelapa baru. Volume santan kelapa, dan penamabahan laru minyak (ragi minyak) dapat mempengaruhi minyak yang dihasilkan. Ragi minyak menghidrolisis protein yang terdapat pada santan yang berperan sebagai elmusifier pada santan. Rusaknya protein maka emulsi minyak dan air pada santan akan rusak dan minyak akan terpisah dari air dengan sendirinya. Bertambahnya volume santan kelapa, maka proses hidrolisis 
protein pada santan akan berlangsung lebih baik sehingga jumlah minyak yang dihasilkan akan lebih banyak.

Hasil analisis sidik ragam menujukan bahwa perlakuan variasi volume santan kelapa tidak berbeda nyata terhadap rendemen minyak yang dihasilkan. Penambahan santan kelapa pada santan instan tidak kadaluarsa masing-masing dilakukan dengan variasi penambahan 5 $\mathrm{ml}, 10 \mathrm{ml}, 15 \mathrm{ml}$, dan $20 \mathrm{ml}$. Hasil menujukan bahwa rendemen minyak yang terbanyak atau tertinggi berada pada penambahan santan kelapa $20 \mathrm{~mL}$.

Pengaruh penambahan laru minyak terhadap rendemen minyak yang dihasilkan, dapat diketahui dengan berbagai variasi volume laru minyak. Hasil yang diperoleh menunjukan rendemen minyak tertinggi (22\%) terdapat pada penggunaan laru minyak $1,50 \mathrm{ml}$. dan rendemen terendah (12\%) ditemukan pada penggunaan laru minyak $0,5 \mathrm{ml}$. Hubungan laru minyak dengan rendemen minyak yang dihasilkan diperlihatkan pada Gambar 3.

Gambar 3 memperlihatkan bahwa dengan meningkatnya penambahan laru minyak, maka rendemen minyak yang dihasilkan juga meningkat. Laru minyak akan menghidrolisis protein yang terdapat pada santan yang berperan sebagai emulsifier pada santan. Rusaknya protein pada santan kelapa menyebabkan emulsi minyak dan air pada santan akan pecah dan minyak akan terpisah dari air dengan sendirinya. Bertambahnya volume laru minyak, maka proses hidrolisis protein pada santan akan berlangsung lebih baik sehingga jumlah minyak yang dihasilkan akan lebih banyak.

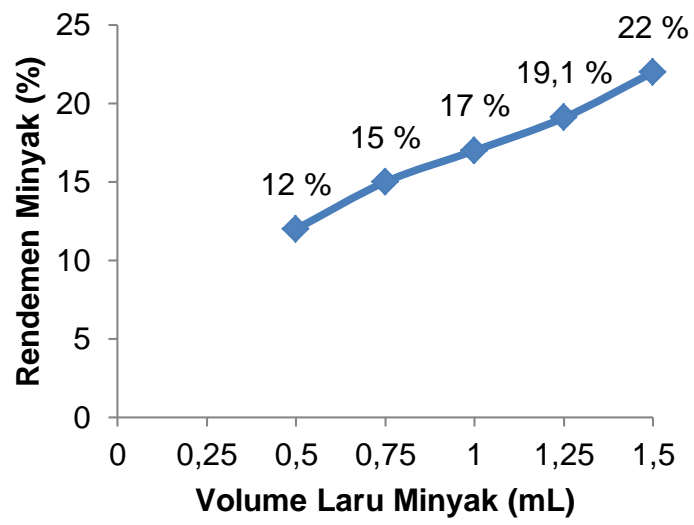

Gambar 3 Kurva hubungan volume laru minyak terhadap rendemen minyak.

Hasil analisis sidik ragam menunjukan bahwa perlakuan variasi laru minyak berpengaruh sangat nyata terhadap rendemen minyak yang dihasilkan. Hasil analisis lanjut menggunakan BNJ (Beda Nyata Jujur) pada taraf $5 \%$ dan $1 \%$ menunjukan nilai rendemen pada penggunaan laru minyak $0,5 \mathrm{~mL}$ berbeda nyata dengan penggunaan $1,25 \mathrm{~mL}$ dan 1,5 mL, dan penggunaan laru minyak 1,25 $\mathrm{mL}$ berbeda tidak nyata dengan penggunaan laru minyak 1,50 $\mathrm{mL}$. Pengaruh penambahan laru minyak terhadap rendemen minyak yang dihasilkan, dari santan instan tidak kadaluarsa sebagai pembanding pada santan instan kadaluarsa dapat diketahui dengan berbagai variasi volume laru minyak. Hasil yang diperoleh menunjukan rendemen minyak tertinggi (25\%) terdapat pada penggunaan laru minyak $1,50 \mathrm{ml}$. 
dan rendemen terendah (11,6\%) ditemukan pada penggunaan laru minyak 0,5 ml. Hubungan laru minyak dengan rendemen minyak yang dihasilkan diperlihatkan pada Gambar 4 sebagai berikut.

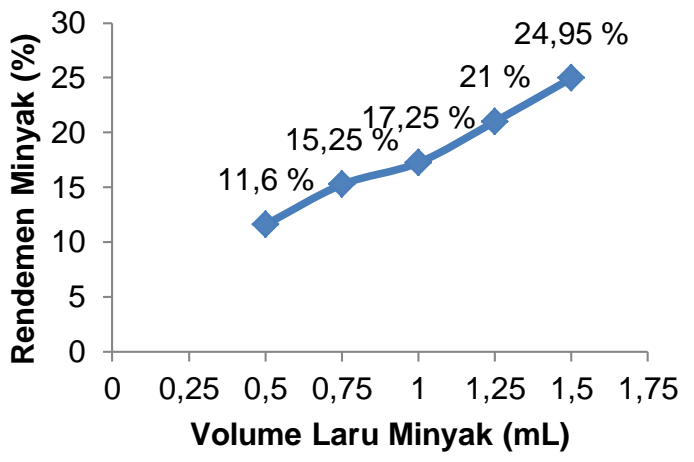

Gambar 4 Kurva hubungan penambahan volume laru minyak terhadap rendemen minyak.

Gambar 4 memperlihatkan bahwa dengan meningkatnya penambahan laru minyak, maka rendemen minyak yang dihasilkan juga meningkat. Laru minyak akan menghidrolisis protein yang terdapat pada santan yang berperan sebagai emulsifier pada santan. Rusaknya protein pada santan kelapa menyebabkan emulsi minyak dan air pada santan akan pecah dan minyak akan terpisah dari air dengan sendirinya. Bertambahnya volume laru minyak, maka proses hidrolisis protein pada santan akan berlangsung lebih baik sehingga jumlah minyak yang dihasilkan akan lebih banyak.

Hasil analisis sidik ragam menunjukan bahwa perlakuan variasi laru minyak berpengaruh sangat nyata terhadap rendemen minyak yang dihasilkan. Hasil analisis lanjut menggunakan BNJ pada taraf $5 \%$ dan $1 \%$ menunjukan nilai rendemen pada penggunaan laru minyak $1,50 \mathrm{~mL}$ dengan nilai 24,95 , berbeda nyata dari penggunaan laru minyak $0,5 \mathrm{~mL}, 0,75$ $\mathrm{mL}, 1 \mathrm{~mL}$ dan $1,25 \mathrm{~mL}$.

Variasi waktu fermentasi terhadap rendemen minyak yang dihasilkan dapat diketahui dengan menerapkan berbagai waktu inkubasi. Hasil rendemen minyak yang di peroleh menunjukan rendemen minyak tertinggi (28\%) terdapat pada penggunaan waktu 30 jam, dan rendemen miyak terendah (15\%) ditemukan pada penggunaan waktu 18 jam. Hasil analisis sidik ragam menunjukan bahwa perlakuan variasi waktu inkubasi berpengaruh berbeda tidak nyata terhadap rendemen minyak yang dihasilkan. Hasil analisis lanjut menggunakan $\mathrm{BNJ}$ pada taraf $5 \%$ dan $1 \%$ menunjukan nilai rendemen pada penggunaan waktu inkubasi 30 jam dengan nilai 28 dan rendemen terendah pada penggunaan waktu inkubasi 18 jam dengan nilai 15. Hubungan waktu inkubasi dengan rendemen minyak yang dihasilkan diperlihatkan pada gambar 5 sebagai berikut.

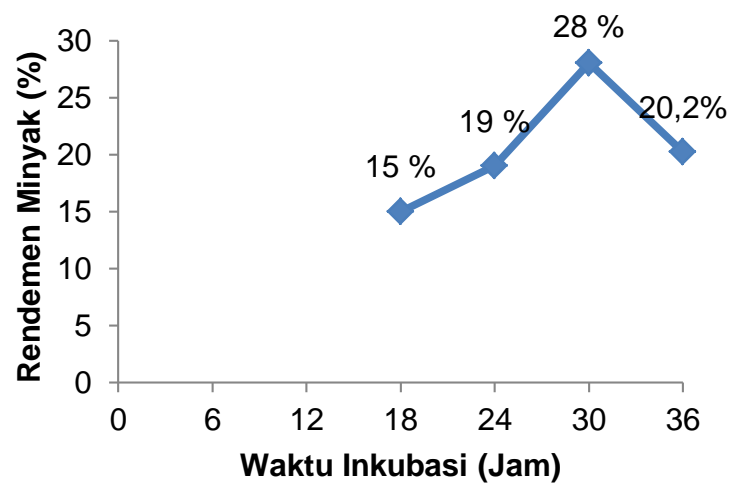

Gambar 5 Kurva hubungan waktu inkubasi terhadap rendemen minyak 
Gambar 5 memperlihatkan bahwa rendemen minyak meningkat sampai waktu inkubasi 30 jam, namun pada penggunaan waktu inkubasi 36 jam terjadi penurunan rendemen minyak. Bertambahnya waktu, maka lama kontak laru minyak dengan substrat (santan) akan lebih lama sehingga dapat terjadi penurunan rendemen minyak. Hal ini membuktikan bahwa lamanya waktu penyimpanan berpengaruh terhadap jumlah minyak yang dihasilkan.

Variasi waktu fermentasi pada santan instan tidak kadaluarsa sebagai pembanding santan instan kadaluarsa terhadap rendemen minyak yang dihasilkan dapat diketahui dengan menerapkan berbagai waktu inkubasi. Hasil rendemen minyak yang diperoleh menunjukan rendemen minyak tertinggi $(21,91 \%)$ terdapat pada penggunaan waktu 30 jam, dan rendemen miyak terendah $(12,5 \%)$ ditemukan pada penggunaan waktu 18 jam. Hasil analisis sidik ragam menunjukan bahwa perlakuan variasi waktu inkubasi berpengaruh berbeda tidak nyata terhadap rendemen minyak yang dihasilkan. Hasil analisis lanjut menggunakan BNJ pada taraf $5 \%$ dan $1 \%$ menunjukan nilai rendemen pada penggunaan waktu inkubasi 30 jam dengan nilai 21,85 dan rendemen terendah pada penggunaan waktu inkubasi 18 jam dengan nilai 12,45. Hubungan waktu inkubasi dengan rendemen minyak yang dihasilkan diperlihatkan pada gambar 6 sebagai berikut.

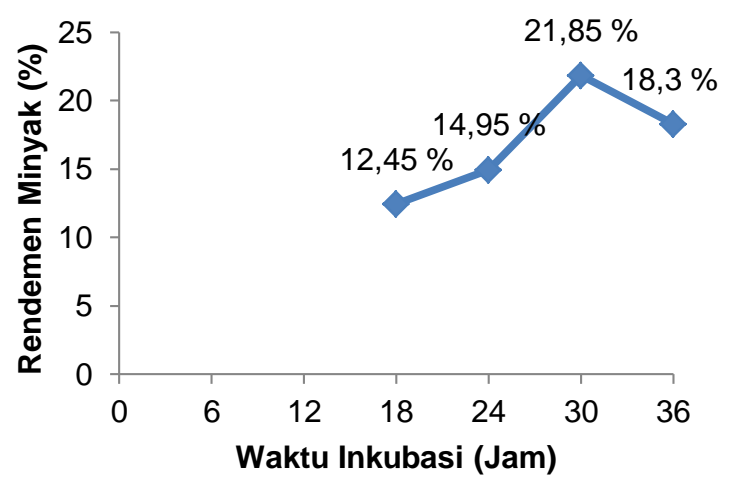

Gambar 6 Kurva hubungan waktu inkubasi terhadap rendemen minyak.

Gambar 6 memperlihatkan bahwa rendemen minyak meningkat sampai waktu inkubasi 30 jam, namun pada penggunaan waktu inkubasi 36 jam terjadi penurunan rendemen minyak. Bertambahnya waktu, maka lama kontak laru minyak dengan substrat (santan) akan lebih lama sehingga dapat terjadi penurunan rendemen minyak. Hal ini membuktikan bahwa lamanya waktu penyimpanan berpengaruh terhadap jumlah minyak yang dihasilkan.

Pembuatan minyak kelapa virgin menggunakan enzim papain yang dilakukan oleh Rasyid (2005) didapatkan rendemen tertinggi (10,54\%) dihasilkan pada penggunaan konsentrasi enzim papain $0,25 \%$. Sedangkan pembuatan VCO secara fermentasi menggunakan strater laru minyak oleh Diana (2005) didapatkan rendemen bekisar antara $10,21 \%-11,75 \%$.

\section{Kadar Air Minyak}

Kandungan air dalam bahan pangan sendiri menentukan kesegaran dan daya tahan bahan itu. Kadar air dalam minyak sendiri merupakan salah satu parameter 
dalam menentukan kualitas suatu minyak. Menurut Winarno (1982), dengan adanya air, minyak atau lemak dapat terhidrolisis menjadi gliserol dan asam lemak. Hidrolisis sanagat menurunkan mutu suatu minyak. Minyak yang telah terhidrolisis, kualitas minyaknya menurun, bahan-bahan menjadi coklat, dan lebih banyak menyerap minyak. Kadar air untuk VCO menurut SNI (2008), maksimal 0,2\%.

Volume laru minyak berpengaruh terhadap kadar air dari minyak yang dihasikan, berdasarkan hasil analisis kadar air menggunakan metode oven. Hasil yang diperoleh menunjukan kadar air pada santan instan kadaluarsa 0,026\%, sedangkan kadar air pada santan instan tidak kadaluarsa 0,007\% . Nilai kadar air VCO yang dihasikan lebih kecil dibandingkan nilai kadar air yang dipersyaratkan oleh Badan Standar Nasional Indonesia sehingga mutunya dinilai sangat baik.

Pembuatan minyak kelapa virgin menggunakan enzim papain yang dilakukan oleh Rasyid (2005) didapatkan kadar air VCO berkisar antara 0,45\% $1,77 \%$. Sedangkan pembuatan VCO secara fermentasi menggunakan starter laru minyak oleh Diana (2005) didapatkan kadar air VCO berkisar antara 0,24\% $0,27 \%$, dan pembuatan VCO menggunakan inokulum laru minyak oleh Norma (2005) di dapatkan kadar airnya berkisar antara $0,015 \%-0,4 \%$.

\section{Kadar FFA}

Asam lemak bebas atau Free Fatty Acid (FFA) merupakan asam lemak yang terbentuk karena terjadinya reaksi hidrolisis lemak atau minyak. Kandungan asam lemak bebas dalam suatu minyak merupakan salah satu parameter penentu kualitas/mutu minyak itu sendiri. Semakin besar kadar asam lemak bebasnya maka semakin rendah kualitas minyak itu. Meunrut SNI (2008) kandungan asam lemak bebas maksimal VCO 0,20\%.

Kadar asam lemak bebas minyak yang dihasilkan menunjukan asam lemak bebas pada santan instan kadaluarsa 0,073\%, sedangkan kadar asam lemak bebas pada santan instan tidak kadaluarsa 0,067\%. Nilai kadar asam lemak bebas yang dipersyaratkan oleh Badan Standar Nasional Indonesia mutu minyak yang dihasilkan dinilai sangat baik.

Pembuatan minyak kelapa virgin menggunakan enzim papain yang dilakukan oleh Rasyid (2005) didapatkan kadar asam lemak bebas VCO berkisar antara 2,84\% - 6,87\% sedangkan pembuatan VCO secara fermentasi menggunakan starter laru minyak oleh Diana (2005) didapatkan kadar asam lemak bebas VCO berkisar antara 0,012\% - 0,015\%, dan pembuatan VCO menggunakan inokulum laru minyak oleh Norma (2005) didapatkan kadar asam lemak bebas VCO berkisar antara 0,44\% $0,67 \%$. 


\section{Bilangan Peroksida}

Bilangan peroksida merupakan parameter penting yang dapat dijadikan acuan untuk menentu-kan derajat kerusakan minyak. Angka peroksida terbentuk karena asam lemak tidak jenuh dapat mengikat oksigen pada ikatan rangkapnya, proses itu dikenal sebagai proses oksidasi. Semakin besar bilangan peroksida minyak yang dihasikan, maka semakin rendah kualitas/mutu minyak dan dapat membahayakan minyak untuk dikonsumsi dalam hal ini bersifat racun. Menurut SNI (2008) kandungan bilangan peroksida maksimal VCO $2 \mathrm{meq} / \mathrm{kg}$.

Bilangan peroksida, minyak yang dihasilkan menunjukan bilangan peroksida tertinggi santan instan kadaluarsa 2,18 meq/1000 gr, sedangkan bilangan peroksida tertinggi pada santan instan tidak kadaluarsa 1,49 meq/1000 gr. Nilai kadar bilangan peroksida yang dipersyaratkan oleh Badan Standar Nasional Indonesia mutu minyak yang dihasilkan dinilai masih baik.

\section{KESIMPULAN}

Jumlah santan kelapa baru yang ditambahkan pada santan instan kadaluarsa dengan rendemen minyak tertinggi $33,5 \%$ adalah $10 \mathrm{~mL}$. Jumlah laru minyak yang ditambahkan pada santan instan kadaluarsa dengan rendemen minyak tertinggi $22 \%$, adalah $1,50 \mathrm{~mL}$. Waktu fermentasi terhadap rendemen minyak tertinggi santan instan kadaluarsa 28\% dengan waktu inkubasi 30 jam.
Minyak yang dihasilkan dari santan instan kadaluarsa dapat digunakan untuk konsumsi karena FFA 0,073\%, bilangan peroksida 2,18 meq/kg dan kadar air $0,026 \%$. Karena minyak dibawah SNI (Kadar air 0,2\%; FFA 0,2\%; dan Bilangan peroksida $2 \mathrm{meq} / 1000 \mathrm{gr}$ ).

\section{DAFTAR PUSTAKA}

Adi R, Amprasto. 1995. Pembuatan Minyak Secara Fermentasi Dengan Menggunakan Jamur Ragi. [Skripsi]. Bandung: Fakultas Pendidikan Matematika dan IImu Pengetahuan Alam IKIP.

Andriani. 2002. Pengaruh Penambahan Beberapa Jenis Antioksidan dan Lama Simpan terhadap Perubahan Sifat Fisik, Kimia, Mikrobiologi, dan Organoleptik Yogurt Santan Kelapa. [Skripsi]. Bandar Lampung: Universitas Lampung.

Anggrahini S. 1999. Pengaruh Penambahan CMC dan Kuning Telur terhadap karateristik santan instan. Prosiding seminar nasional pangan. PAU UGM. Yogyakarta.

Arsa, M., A. A. Bawa Putra, Emmy Sahara, I. A.R. Astiti Asih, Ni W Bogoriani, I G A.Gede Bawa, dan I N. Simpen. 2004. Pembuatan Minyak Kelapa dengan Metode Fermentasi, Udayana Mengabdi 3 (1) : 21-26

Suastuti NGAMDA. 2009. Kadar air dan bilangan asam dari minyak kelapa yang dibuat dengan cara tradisional dan fermentasi. Jurusan kimia. FMIPA Universitas Udayana. Bukit jimbaran. Jurnal Kimia. 3 (2): 69-74

Diana. 2005. Pembuatan Minyak Kelapa Virgin Secara Fermentasi Menggunakan Starter Laru Minyak. (Skripsi). Palu: Fakultas Pertanian Universitas Tadulako.

Djatmiko B. 1983. Studi Mengenai Stabilitas Emulsi Santan. Dalam Studi Tentang Serat Daging Buah dari Beberapa Varietas Kelapa dan Tentang Stabilitas Emulsi Santan, 
[Skripsi]. Bogor: Jurusan Teknologi Industri. FATETA-IPB.

Hasbullah. 2001. Teknologi Tepat Guna Agroindustri Kecil Sumatera Barat, E. Sawedi, (Ed) Dewan Ilmu Pengetahuan, Teknologi dan Industri Sumatera Barat. (http://Www.lptek. Net.Id/Ind/Warintek/Pengolahan_Pan gan_ldx.Php?Doc=6a8). diakses tanggal 20 Oktober 2015.

Ketaren S. 1986. Pengantar Teknologi Minyak dan Lemak Pangan. Jakarta: UI-Press.

Norma. 2005. Pembuatan Minyak Kelapa Virgin Secara Fermentasi Menggunakan Inokulum Laru Minyak. [Skripsi]. Palu: Fakultas Pertanian Universitas Tadulako.

Rasyid AA. 2005. Pembuatan Minyak Kelapa Virgin Secara Enzimatik Menggunakan Enzim Papain. [Skripsi]. Palu: Fakultas Pertanian Universitas Tadulako.

Rindengan B., A. Lay., H. Novarianto., H. Kembuan, Z. Mahmud. 1995. Karakterisasi daging buah Kelapa Hirbida untuk bahan baku industri makanan. [Laporan Hasil Penelitian]. Kerjasama Proyek Pembinaan Kelembagaan Penelitian Pertanian Nasional, Badan Litbang. 49 hal.

Suhadijono, Syamsiah. 1988. Pembuatan Minyak Kelapa Dengan Cara Fermentasi. Yogyakarta: Penerbit Liberty.

Sukmadi B., Nugroho NB. 2002. Kajian Penggunaan Inokulum pada Produksi Minyak Kelapa Secara Fermentasi. Jurnal Biosains dan Bioteknologi Indonesia. 2(1): 12-17

Tansakul A., Chaisawang P. 2006. Thermophysical properties of coconut milk. J.Food Enginnering 73:276-280.

Winarno, F. G., 1982, Kimia Pangan dan Gizi. Jakarta: PT. Gramedia Utama. 